\title{
Analysis of Factors Influencing the Completeness of the MCH Handbook Document as an Early Detection of High-Risk Trimester III Pregnant Women by a Midwife in West Kotawaringin
}

\author{
Siti Zakiah ${ }^{1}$, Bayba Melda \\ Suhita $^{2}$, Yenny Puspitasari ${ }^{3}$ \\ ${ }^{1}$ Master Program of \\ Public Health, Institute of Health \\ Sciences Strada Indonesia \\ ${ }^{2}$ Master Program of \\ Public Health, Institute of Health \\ Sciences Strada Indonesia \\ ${ }^{3}$ Master Program of \\ Public Health, Institute of Health \\ Sciences Strada Indonesia \\ E-mail: \\ zakiah.pbun@gmail.com
}

Received : May $8^{\text {th }} 2021$

Accepted : May 10 2021

Published : May 20 2021

\begin{abstract}
The MCH Handbook is a tool for early detection of maternal and child health problems, guiding officers to document properly and correctly. The purpose of this study was to determine the effect of knowledge, workload, availability of tools and facilities, monitoring and evaluation of the Coordinating Midwife on completeness of MCH book documentation for mothers. This Study use Quantitative Cross Sectional, the population of midwives in 18 health centers and their networks, a sample size of 102 respondents with the Cluster Random sampling technique and the logistic regression statistical test used the backward stepwise (wald) test with significance $\leq(\alpha 0.05)$. Result of this study are The influence of knowledge significance (0.301) workload (sig 0.647) availability of tools and facilities (sig 0.025), monitoring and evaluation by coordinating midwives (sig 0.035) simultaneously affect the completeness of $\mathrm{MCH}$ book documents for pregnant women in the third trimester, the Nagelkerke R Square coefficient is obtained $(62.6 \%$,). The $\mathrm{MCH}$ book document is influenced by the midwife's knowledge of the MCH handbook, the availability of tools and facilities and monitoring and evaluation by the Coordinating Midwife. The dominant factor that has the most influence is monitoring and evaluation by the coordinating midwife (Exp. B: 6,969).
\end{abstract}

Keywords: MCH handbook, midwives, documents completeness, pregnant women

Copyright @ 2021 IIK STRADA Indonesia All right reserved.

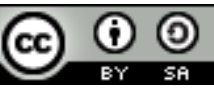

This is an open-acces article distributed under the terms of the Creative Commons AttributionShareAlike 4.0 International License. 


\section{INTRODUCTION}

The MCH Handbook is a tool for early detection of problems with maternal and child health, a communication tool and a tool for counseling with important information for mothers and families and the community regarding maternal and child health services including references and packages (standard) of $\mathrm{MCH}$ services, nutrition, immunization and development of children under five. The use of MCH books has not been optimal in supporting the survival and quality of life of mothers and children. Understanding of health workers about the benefits of $\mathrm{MCH}$ books as IEC media and $\mathrm{MCH}$ service recording documents is important, using the KIA book as an integral part of providing $\mathrm{MCH}$ services (Ministry of Health RI, 2015)Based on the results of the 2018 Riskesdas survey, it was reported that there were still $30 \%$ of pregnant women who did not have a $\mathrm{MCH}$ booklet, $10 \%$ of pregnant women stated that they had a KIA book but could not show it when the survey was conducted, and as many as $60 \%$ of pregnant women stated that they had a $\mathrm{MCH}$ book and could show it. during the survey (Riskesdas Report, 2018)

The period of pregnancy is one of the most important moments in the process of motherhood. However, it should be noted that pregnant women also have various risks that can kill the mother's own life. In this case it is called high risk pregnant women. High-risk pregnant women are a time when the mother can experience various risks during pregnancy (Prawirohardjo, 2014). Complications of pregnancy and childbirth can be detected as early as possible by doing an integrated antenatal. In integrated Antenatal services, health workers must be able to ensure that health is normal, able to detect problems and illnesses experienced by pregnant women early, intervene adequately so that pregnant women are ready to undergo normal labor. Antenatal services must be carried out routinely, according to standards and integrated for quality antenatal care. (Ministry of Health RI 2010)

In 2018 Kumai Public Health Center has reported the results of risk detection carried out by health workers totaling 202 cases and visits of pregnant women in trimester III (K4) amounted to 860 (84.98\%) and there were 2 maternal deaths that occurred in the working area of Kumai Public Health Center. A Maternal Perinatal Audit (AMP) has been carried out by the District AMP team, in the case analysis, maternal mortality should have been prevented, if only health personnel (midwives) had carried out an integrated antenatal program and had recorded all results and disease history in the MCH Handbook.

To be able to fill in the $\mathrm{MCH}$ handbook properly and correctly, health workers should understand the technical instructions for the $\mathrm{MCH}$ handbook. The technical guidelines for using the maternal and child health book contain the understanding and use of the MCH handbook for health workers, the use of the $\mathrm{MCH}$ handbook and how to fill in the $\mathrm{MCH}$ handbook by mothers, husbands, families / caregivers of children in pantidan or child social welfare institutions and cadres. (Kemenkes RI, 2015) The midwife coordinating the Public Health Center is assisted by the person in charge of the village / village unit to monitor the implementation of the $\mathrm{MCH}$ handbook, integrated with other MCH programs, this aims to see the continuity and improvement of the quality of use and utilization of the MCH book and to identify constraints and supporting factors for use. KIA booklet at the community and cadre level. The Puskesmas Coordinator Midwife guides health workers who provide $\mathrm{MCH}$ services in their working areas to use the MCH Handbook for every service provided, including the use of the MCH Handbook when referring. Monitoring activities and fostering the application of the MCH Handbook also include; what is the role of health facilities and health workers in carrying out their functions as providers of $\mathrm{MCH}$ services and the role of health workers as facilitators for mothers/families, cadres and the community in implementing the MCH Handbook (Ministry of Health, 2015). The availability of service facilities as one of the supporting factors that should not be forgotten. The means or tools in question are all types of equipment, work equipment and other facilities that function as the main tool / assistant in carrying out work (Gibson in Tri Anasari, 2012).

\section{MATERIALS AND METHODS}

The design in this study is Quantitative with a cross sectional approach. The study was conducted in October 2019, in this study consisted of 4 X variables, namely the respondent's knowledge of the MCH Handbook, the respondent's workload, the availability of tools and facilities 
as well as monitoring and evaluation of the coordinating midwife. While the $\mathrm{Y}$ variable is the completeness of the $\mathrm{MCH}$ booklet document for pregnant women in the third trimester. The population in this study were midwives in Kotawaringin Barat district who worked at 18 health centers and their network with a sample size of 102 respondents, using the cluster random sampling technique, the instrument used in this study was a questionnaire that had been tested for validity for variable $\mathrm{X}$ and observation sheets. For variable $\mathrm{Y}$, the statistical test used is logistic regression on the backward stepwise (Wald) test with significance $\leq(\alpha 0.05)$.

Table 1. Distribution of respondent characteristics

\begin{tabular}{llc}
\hline Characteristics & F & \% \\
\hline Age (Th) & & \\
$<35$ & 47 & 46.1 \\
$>35$ & 55 & 53.9 \\
\hline Education & 98 & \\
D-III Midwifery & 3 & 97.06 \\
D-IV Midwifery & & \\
\hline Years of service & 40 & 39.2 \\
<10 Years & 62 & 60.8 \\
$>$ 10 Years & & \\
\hline Workplace & 36 & 35.3 \\
Secondary Public Health Center & 48 & 47.1 \\
Main Public Health Center & 18 & 17.6 \\
Inpatient Public Health Center &
\end{tabular}

From the table above, it can be seen that more than some of the respondents were over 35 years of age as many as 55 respondents $(53.9 \%)$ and almost all of the respondents had a DIII midwifery education as many as 99 respondents $(97.06 \%)$, with a lot of work periods above 10 years. as many as 62 respondents $(60.8 \%)$ and most of the respondents worked at the main Public Health Center as many as 48 people $(47.1 \%)$.

Table 2. Frequency distribution of variables

\begin{tabular}{lll}
\hline Knowledge of the KIA book & F & $\%$ \\
Less & 0 & 0 \\
Moderate & 12 & 11.8 \\
Well & 90 & 88.2 \\
\hline Workload & 0 & 0 \\
Below average & 88 & 86.3 \\
Average & 14 & 13.7 \\
Above average & & \\
\hline Availability of tools \& facilities & 47 & 46.1 \\
Complete & 55 & 53.9 \\
Incomplete & 20 & 19.6 \\
\hline $\begin{array}{l}\text { Monitoring and Evaluation of } \\
\text { Coordinating Midwives }\end{array}$ & 82 & 80.4 \\
Not Monev & & \\
Monev & & 85.3 \\
\hline The completeness of document & 87 & 14.7 \\
Incomplete & 15 & $\mathrm{k}$ \\
Complete & &
\end{tabular}

From the table above, it can be seen that most of the respondents have knowledge of the good category $\mathrm{MCH}$ handbooklet, as many as 90 people $(88.2 \%)$ most of them have an average workload of 88 respondents $(86.3 \%)$ with the level of availability of tools and facilities more than half Incomplete as many as 55 respondents (53.9\%), and received monitoring and evaluation by the coordinating midwife as many as 82 respondents $(80.4 \%)$, 
but on the completeness of the MCH Handbook documents 87 respondents $(85.3 \%)$ did documentation of the MCH Handbook incomplete.

Table 3: The results of cross tabulation on the respondent's knowledge variable about the kia book (X1) with the respondent's age

\begin{tabular}{|c|c|c|c|c|c|c|c|c|c|}
\hline \multirow{3}{*}{ No. } & \multirow{3}{*}{$\begin{array}{c}\text { Respondent } \\
\text { age }\end{array}$} & \multicolumn{6}{|c|}{ Respondents' Knowledge } & \multirow{2}{*}{\multicolumn{2}{|c|}{ Total }} \\
\hline & & \multicolumn{2}{|c|}{ Less } & \multicolumn{2}{|c|}{ Moderate } & \multicolumn{2}{|c|}{ Well } & & \\
\hline & & $\mathbf{F}$ & $\%$ & $\mathbf{F}$ & $\%$ & $\mathbf{F}$ & $\%$ & $\mathbf{F}$ & $\%$ \\
\hline 1 & $<35$ years & 0 & 0 & 4 & 3,9 & 43 & 42.2 & 47 & 46.1 \\
\hline 2 & $>35$ years & 0 & 0 & 8 & 7,8 & 47 & 46.0 & 55 & 53.9 \\
\hline & Total & 0 & 0 & 12 & 11.7 & 90 & 88.2 & 102 & 100 \\
\hline
\end{tabular}

There is no correlation between age and respondents' knowledge of the $\mathrm{MCH}$ booklet (p Phi 0.346>0.05)

Based on table 3 above, it is known that almost half of the respondents who have good knowledge are over 35 years of age as many as 47 people $(46.1 \%)$

Table 4. The results of cross tabulation on the respondent's knowledge variable about the kia book (X1) with the respondent's education

\begin{tabular}{|c|c|c|c|c|c|c|c|c|c|}
\hline \multirow{3}{*}{ No. } & \multirow{3}{*}{$\begin{array}{l}\text { Respondent } \\
\text { Education }\end{array}$} & \multicolumn{6}{|c|}{ Respondents' Knowledge } & \multirow{2}{*}{\multicolumn{2}{|c|}{ Total }} \\
\hline & & \multicolumn{2}{|c|}{ Less } & \multicolumn{2}{|c|}{ Moderate } & \multicolumn{2}{|c|}{ Well } & & \\
\hline & & $\mathbf{F}$ & $\%$ & $\mathbf{F}$ & $\%$ & $\mathbf{F}$ & $\%$ & $\mathbf{F}$ & $\%$ \\
\hline 1 & $\begin{array}{l}\text { D III - } \\
\text { Midwifery }\end{array}$ & 0 & 0 & 12 & 11.8 & 87 & 85.3 & 99 & 97.1 \\
\hline 2 & $\begin{array}{l}\text { D IV - } \\
\text { Midwifery }\end{array}$ & 0 & 0 & 0 & 0 & 3 & 2.9 & 3 & 2.9 \\
\hline & Total & 0 & 0 & 12 & 11.8 & 90 & 88.2 & 102 & 100 \\
\hline
\end{tabular}

There is no education of respondents with knowledge of the KIA book on the respondent's knowledge of the MCH handbook ( $\mathrm{p}$ Phi0.521>0.05)

Based on table 4 above, it is known that respondents who have good knowledge of MCH books are those who have D III midwifery education as many as 87 people $(85.3 \%)$

Table 5. The results of cross tabulation on the respondent's knowledge variable about the kia book (X1) with the respondent's tenure

\begin{tabular}{|c|c|c|c|c|c|c|c|c|c|}
\hline \multirow{3}{*}{ No. } & \multirow{3}{*}{$\begin{array}{l}\text { Years of } \\
\text { service }\end{array}$} & \multicolumn{6}{|c|}{ Respondents' Knowledge } & \multirow{2}{*}{\multicolumn{2}{|c|}{ Total }} \\
\hline & & \multicolumn{2}{|c|}{ Less } & \multicolumn{2}{|c|}{ Moderate } & \multicolumn{2}{|c|}{ Well } & & \\
\hline & & $\mathrm{F}$ & $\%$ & $\mathrm{~F}$ & $\%$ & $\mathrm{~F}$ & $\%$ & $\mathrm{~F}$ & $\%$ \\
\hline 1 & $<10$ years & 0 & 0 & 3 & 2.9 & 37 & 36.3 & 99 & 97.1 \\
\hline 2 & $>10$ years & 0 & 0 & 9 & 8.9 & 53 & 51.9 & 3 & 2.9 \\
\hline & Total & 0 & 0 & 12 & 11.8 & 90 & 88.2 & 102 & 100 \\
\hline
\end{tabular}

There is no relationship between years of service and knowledge of the maturity of the MCH handbook (p Phi 0.283>0.05)

Based on table 5 above, it is known that some of the respondents who had a service period of $>10$ years who had good knowledge of the MCH handbook were as many as 53 people (51.9\%). 
Table 6. The results of cross tabulation on the respondent's knowledge variable about the kia book (X1) and the respondent's workplace

\begin{tabular}{|c|c|c|c|c|c|c|c|c|c|}
\hline \multirow{3}{*}{ No. } & \multirow{3}{*}{ Workplace } & \multicolumn{6}{|c|}{ Knowledge } & \multirow{2}{*}{\multicolumn{2}{|c|}{ Total }} \\
\hline & & \multicolumn{2}{|c|}{ Less } & \multicolumn{2}{|c|}{ Moderate } & \multicolumn{2}{|c|}{ well } & & \\
\hline & & $\mathbf{F}$ & $\%$ & $\mathbf{F}$ & $\%$ & $\mathbf{F}$ & $\%$ & $\mathbf{F}$ & $\%$ \\
\hline \multirow[t]{2}{*}{1} & Secondary & & & & & & & & \\
\hline & $\begin{array}{l}\text { Public health } \\
\text { center }\end{array}$ & 0 & 0 & 3 & 2.9 & 33 & 32.4 & 36 & 35.3 \\
\hline 2 & $\begin{array}{l}\text { Main Public } \\
\text { health center }\end{array}$ & 0 & 0 & 8 & 7,8 & 40 & 39.2 & 48 & 47.1 \\
\hline 3 & $\begin{array}{l}\text { Inpatient Public } \\
\text { health center }\end{array}$ & 0 & 0 & 1 & 0.9 & 17 & 16.7 & 18 & 17.6 \\
\hline & Total & 0 & 0 & 12 & 11.7 & 90 & 88.2 & 102 & 100 \\
\hline
\end{tabular}

There is no correlation between the respondent's workplace, the respondent's knowledge of the KIA book ( $p$ Phi 0.335>0.05)

Based on table 6, it is known that respondents who have good knowledge of the MCH book work at the Main Puskesmas as many as 40 people or $(39.2 \%)$

Table 7 Cross tabulation results on the respondent's workload variable (X2) with the age of the respondent

\begin{tabular}{|c|c|c|c|c|c|c|c|c|c|}
\hline \multirow{3}{*}{ No. } & \multirow{3}{*}{$\begin{array}{c}\text { Respondent } \\
\text { age }\end{array}$} & \multicolumn{6}{|c|}{ Respondents Workload } & \multirow{2}{*}{\multicolumn{2}{|c|}{ Total }} \\
\hline & & \multicolumn{2}{|c|}{ Under } & \multicolumn{2}{|c|}{ Average } & \multicolumn{2}{|c|}{ Above } & & \\
\hline & & $\mathbf{F}$ & $\%$ & $\mathbf{F}$ & $\%$ & $\mathbf{F}$ & $\%$ & $\mathbf{F}$ & $\%$ \\
\hline 1 & $<35$ years & 0 & 0 & 40 & 39.2 & 7 & 6.8 & 47 & 46.1 \\
\hline 2 & $>35$ years & 0 & 0 & 48 & 47.0 & 7 & 6.8 & 55 & 53.9 \\
\hline & Total & 0 & 0 & 88 & 86.2 & 14 & 13.7 & 102 & 100 \\
\hline
\end{tabular}

There is no correlation between age and the respondent's workload (p Phi0.751> $0.05)$

Based on table 7 above, it is known that almost half of the respondents who have an average workload over 35 years of age are 47 people $(46.1 \%)$

Table 8: Cross tabulation results on the respondent's workload variable (X2) with the respondent's education

\begin{tabular}{|c|c|c|c|c|c|c|c|c|c|}
\hline \multirow{3}{*}{ No. } & \multirow{3}{*}{$\begin{array}{l}\text { Education } \\
\text { Respondents }\end{array}$} & \multicolumn{6}{|c|}{ Respondent workload } & \multirow{2}{*}{\multicolumn{2}{|c|}{ Total }} \\
\hline & & \multicolumn{2}{|c|}{ Under } & \multicolumn{2}{|c|}{ Average } & \multicolumn{2}{|c|}{ Above } & & \\
\hline & & $\mathbf{F}$ & $\%$ & $\mathbf{F}$ & $\%$ & $\mathbf{F}$ & $\%$ & $\mathbf{F}$ & $\%$ \\
\hline 1 & $\begin{array}{l}\text { D III - } \\
\text { Midwifery }\end{array}$ & 0 & 0 & 85 & 83.3 & 14 & 13.7 & 99 & 97.1 \\
\hline 2 & $\begin{array}{l}\text { D IV - } \\
\text { Midwifery }\end{array}$ & 0 & 0 & 3 & 2.9 & 0 & 0 & 3 & 2.9 \\
\hline & Total & 0 & 0 & 88 & 86.3 & 14 & 13.7 & 102 & 100 \\
\hline
\end{tabular}

There is no relationship between education of respondents and workload (p Phi 0.483> $0.05)$

Based on table 8 above, it is known that respondents who have an average workload are 85 people who have DIII midwifery education (83.3\%)

Table 9 Cross tabulation results on the respondent's workload variable (X2) with the respondent's tenure 


\begin{tabular}{|c|c|c|c|c|c|c|c|c|c|}
\hline \multirow{3}{*}{ No. } & \multirow{3}{*}{$\begin{array}{l}\text { Years of } \\
\text { service }\end{array}$} & \multicolumn{6}{|c|}{ Respondents Workload } & \multirow{2}{*}{\multicolumn{2}{|c|}{ Total }} \\
\hline & & \multicolumn{2}{|c|}{ Under } & \multicolumn{2}{|c|}{ Average } & \multicolumn{2}{|c|}{ Above } & & \\
\hline & & $\mathbf{F}$ & $\%$ & $\mathbf{F}$ & $\%$ & $\mathbf{F}$ & $\%$ & $\mathbf{F}$ & $\%$ \\
\hline 1 & $<10$ ye & 0 & 0 & 36 & 35.3 & 4 & 3,9 & 40 & 39.2 \\
\hline 2 & $>10$ years & 0 & 0 & 52 & 50.9 & 10 & 9.8 & 62 & 60.8 \\
\hline & Total & 0 & 0 & 88 & 86.3 & 90 & 88.2 & 102 & 100 \\
\hline
\end{tabular}

There is no relationship between tenure and the respondent's work load (p Phi 0.380> $0.05)$

From table 9, it is known that the respondents who have an average workload in the service period> 10 years are 52 people $(50.9 \%)$

Table 10. Cross tabulation results on the respondent's workload variable (X2) and the respondent's

\begin{tabular}{|c|c|c|c|c|c|c|c|c|c|}
\hline \multirow{4}{*}{ No. } & \multirow{4}{*}{$\begin{array}{l}\text { The place } \\
\text { Work }\end{array}$} & \multicolumn{6}{|c|}{ workplace } & \multirow{3}{*}{\multicolumn{2}{|c|}{ Total }} \\
\hline & & & & \multicolumn{4}{|c|}{ Workload } & & \\
\hline & & \multicolumn{2}{|c|}{ Under } & & age & \multicolumn{2}{|c|}{ Above } & & \\
\hline & & $\mathbf{F}$ & $\%$ & $\mathbf{F}$ & $\%$ & $\mathbf{F}$ & $\%$ & $\mathbf{F}$ & $\%$ \\
\hline \multirow[t]{2}{*}{1} & Secondary & & & & & & & & \\
\hline & $\begin{array}{l}\text { Public Health } \\
\text { Center }\end{array}$ & 0 & 0 & 34 & 0 & 2 & 1.9 & 36 & 35.3 \\
\hline 2 & $\begin{array}{l}\text { Main Public } \\
\text { health center }\end{array}$ & 0 & 0 & 48 & 47.1 & 0 & 0 & 48 & 47.1 \\
\hline \multirow[t]{2}{*}{3} & $\begin{array}{l}\text { Inpatient Public } \\
\text { Health Center }\end{array}$ & 0 & 0 & 12 & 11.7 & 6 & 5.8 & 18 & 17.6 \\
\hline & Total & 0 & 0 & 94 & 92.2 & 8 & 7,8 & 102 & 100 \\
\hline
\end{tabular}

There is a relationship between the respondent's workplace and the respondent's workload (p Phi $0.00<0.05$ )

From table 10 above, it is known that the respondents who have an average workload mostly work at the Non-Care Main Puskesmas as many as 48 people or $(47.1 \%)$

Table 11 Cross tabulation results on the variable availability of tools and facilities (X3) with the respondent's workplace

\begin{tabular}{|c|c|c|c|c|c|c|c|}
\hline \multirow{3}{*}{ No. } & \multirow{3}{*}{ Workplace } & \multicolumn{4}{|c|}{ Availability of tools and facilities } & \multirow{2}{*}{\multicolumn{2}{|c|}{ Total }} \\
\hline & & \multicolumn{2}{|c|}{ Incomplete } & \multicolumn{2}{|c|}{ Complete } & & \\
\hline & & $\mathbf{F}$ & $\%$ & $\mathbf{F}$ & $\%$ & $\mathbf{f}$ & $\%$ \\
\hline 1 & $\begin{array}{l}\text { Secondary Public } \\
\text { health center }\end{array}$ & 33 & 32.4 & 3 & 2.9 & 36 & 35.3 \\
\hline 2 & $\begin{array}{l}\text { Main Public } \\
\text { health center }\end{array}$ & 19 & 18.6 & 29 & 24.4 & 48 & 47.1 \\
\hline 3 & $\begin{array}{l}\text { Inpatient Public } \\
\text { health center }\end{array}$ & 5 & 4,9 & 13 & 12.7 & 18 & 17.6 \\
\hline \multicolumn{2}{|c|}{ Total } & 57 & 55.9 & 45 & 44.1 & 102 & 100 \\
\hline
\end{tabular}

From table 11, it can be seen that the respondent's workplace where the availability of tools and facilities is incomplete is the Polindes respondents who work in the Polindes as many as 33 respondents $(32.4 \%)$ 
Table 12 Cross tabulation results on the monitoring and evaluation variables of midwives coordinoor (X4) with the respondent's education

\begin{tabular}{|c|c|c|c|c|c|c|c|}
\hline \multirow{3}{*}{ No. } & \multirow{3}{*}{$\begin{array}{l}\text { Respondent } \\
\text { Education }\end{array}$} & \multicolumn{4}{|c|}{ Monev Bikoor } & \multirow{2}{*}{\multicolumn{2}{|c|}{ Total }} \\
\hline & & \multicolumn{2}{|r|}{ Not } & \multicolumn{2}{|c|}{ Monev } & & \\
\hline & & $\mathbf{F}$ & $\%$ & $\mathbf{F}$ & $\%$ & $\mathbf{F}$ & $\%$ \\
\hline 1 & D III Midwifery & 20 & 19.6 & 79 & 77.4 & 99 & 97.1 \\
\hline 2 & D IV Midwifery & 0 & 0 & 3 & 2.9 & 3 & 2.9 \\
\hline & Total & 20 & 19.6 & 82 & 80.4 & 102 & 100 \\
\hline
\end{tabular}

There is no effect of respondent education on the monitoring and evaluation of the coordinating midwife ( $\mathrm{p}$ Phi $0.385>0.05$ )

Based on table 12 above, it is known that the respondents who received monitoring and evaluation by the coordinating midwife were those who had D III midwifery education as many as 79 respondents $(77.5 \%)$.

Table 13. Results of cross tabulation on the monitoring and evaluation variables of midwives coordinoor (X4) with the respondent's tenure

\begin{tabular}{|c|c|c|c|c|c|c|c|}
\hline \multirow{3}{*}{ No. } & \multirow{3}{*}{ Years of service } & \multicolumn{4}{|c|}{ Monev Bikor } & \multirow{2}{*}{\multicolumn{2}{|c|}{ Total }} \\
\hline & & \multicolumn{2}{|c|}{ No } & \multicolumn{2}{|c|}{ Yes } & & \\
\hline & & $\mathbf{F}$ & $\%$ & $\mathbf{F}$ & $\%$ & $\mathbf{F}$ & $\%$ \\
\hline 1 & $<10$ years & 9 & 8.8 & 31 & 30.4 & 40 & 39.2 \\
\hline 2 & $>10$ years & 11 & 10.8 & 51 & 50.0 & 62 & 61.8 \\
\hline & Total & 20 & 18.6 & 82 & 81.4 & 102 & 100 \\
\hline
\end{tabular}

There is no relationship between Respondents' tenure of monitoring and evaluation by the Coordinating Midwife (p Phi 0.555>0.05)

From table 13 it is known that respondents who received a lot of monitoring and evaluation by the coordinating midwife were respondents who had a service period of $>10$ years as many as 51 people or $(50 \%)$.

Table 14 The results of cross tabulation on the monitoring and evaluation variables of the coordinating midwife (X4) with the respondent's workplace

\begin{tabular}{|c|c|c|c|c|c|c|c|}
\hline \multirow{3}{*}{ No. } & \multirow{3}{*}{ Workplace } & \multicolumn{4}{|c|}{$\begin{array}{l}\text { Monitoring Evaluation Coordiantor } \\
\text { Midwife }\end{array}$} & \multirow{2}{*}{\multicolumn{2}{|c|}{ Total }} \\
\hline & & \multicolumn{2}{|c|}{ No } & \multicolumn{2}{|c|}{ Yes } & & \\
\hline & & $\mathrm{F}$ & $\%$ & $\mathrm{~F}$ & $\%$ & $f$ & $\%$ \\
\hline 1 & $\begin{array}{l}\text { Secondary Public } \\
\text { health center }\end{array}$ & 7 & 6.9 & 29 & 28.9 & 36 & 35.3 \\
\hline 2 & $\begin{array}{l}\text { Main Public health } \\
\text { center }\end{array}$ & 11 & 10.8 & 37 & 36.3 & 48 & 47.1 \\
\hline 3 & $\begin{array}{l}\text { Inpatient Public } \\
\text { health center }\end{array}$ & 2 & 1.9 & 16 & 15.7 & 18 & 17.6 \\
\hline Tot & & 20 & 19.6 & 2 & 80.4 & 102 & 100 \\
\hline
\end{tabular}


There is no relationship between the workplace and the monitoring and evaluation of the coordinating midwife ( $\mathrm{p}$ Phi0.0 657> 0.05)

From table 14 above, it can be seen that the most respondents who received monitoring and evaluation by the coordinating midwife were 29 respondents $(24.4 \%)$ who worked at the main health center.

Table 15. Results of cross tabulation of the completeness of the MCH Handbook document (Y) with the age of the respondent

\begin{tabular}{|c|c|c|c|c|c|c|c|}
\hline \multirow{3}{*}{ No. } & \multirow{3}{*}{$\begin{array}{l}\text { Age } \\
\text { Respondents }\end{array}$} & \multicolumn{3}{|c|}{ The completeness of document } & \multirow{2}{*}{\multicolumn{3}{|c|}{ Total }} \\
\hline & & \multirow{2}{*}{$\frac{\text { Incomplete }}{\text { F }}$} & \multicolumn{2}{|c|}{ Complete } & & & \\
\hline & & & $\%$ & FF & $\%$ & $\mathbf{F}$ & $\%$ \\
\hline 1 & $<35$ Years & 44 & 43.1 & 3 & 2.9 & 7 & 46.1 \\
\hline \multirow[t]{2}{*}{2} & $>35$ years & 43 & 42.1 & 12 & 11.7 & 55 & 53.9 \\
\hline & Total & 87 & 85.2 & 15 & 14.7 & 102 & 100 \\
\hline
\end{tabular}

There is an influence on the age of the respondent on the completeness of the KIA book documents ( $\mathrm{p}$ Phi $0.028<0.05$ )

Based on table 15 above, it is known that almost half of the respondents aged <35 years have incomplete documentation in the MCH book, namely 44 people (43.1\%).

Table 16. Results of cross tabulation of the completeness of the KIA book document (Y) with the respondent's education.

\begin{tabular}{|c|c|c|c|c|c|c|c|}
\hline \multirow{3}{*}{ No. } & \multirow{3}{*}{$\begin{array}{l}\text { Respondent } \\
\text { Education }\end{array}$} & \multicolumn{4}{|c|}{ The completeness of document } & \multirow{2}{*}{\multicolumn{2}{|c|}{ Total }} \\
\hline & & \multicolumn{2}{|c|}{ Incomplete } & \multicolumn{2}{|c|}{ Complete } & & \\
\hline & & $\mathbf{F}$ & $\%$ & $\mathbf{F}$ & $\%$ & $\mathbf{F}$ & $\%$ \\
\hline 1 & D III Midwifery & 84 & 82.4 & 15 & 14.7 & 99 & 97.1 \\
\hline 2 & D IV Midwifery & 3 & 2.9 & 0 & 0 & 3 & 2.9 \\
\hline & Total & 87 & 85.3 & 15 & 14.7 & 102 & 100 \\
\hline
\end{tabular}

There is no effect of respondent's education on the completeness of the MCH book document (p Phi 0.465>0.05)

Based on table 16 above, it is known that 84 respondents who had DIII midwifery did not fill in complete $\mathrm{MCH}$ book documents $(82.4 \%)$

Table 17 Results of cross tabulation of the completeness of the MCH Handbook document (Y) with the respondent's working period.

\begin{tabular}{|c|c|c|c|c|c|c|c|}
\hline \multirow{3}{*}{ No. } & \multirow{3}{*}{ Years of service } & \multicolumn{4}{|c|}{ The completeness of document } & \multicolumn{2}{|c|}{ Total } \\
\hline & & \multicolumn{2}{|c|}{ Incomplete } & \multicolumn{2}{|c|}{ Complete } & & \\
\hline & & $\mathbf{F}$ & $\%$ & $\mathbf{F}$ & $\%$ & $\mathbf{f}$ & $\%$ \\
\hline 1 & $<10$ years & 37 & 36.3 & 3 & 2.9 & 40 & 39.2 \\
\hline 2 & $>10$ years & 50 & 49.0 & 12 & 11.8 & 62 & 60.8 \\
\hline \multicolumn{2}{|c|}{ Total } & 87 & 85.3 & 15 & 14.7 & 102 & 100 \\
\hline
\end{tabular}

There is no relationship between the tenure of the respondent on the completeness of the KIA book documents (p Phi 0.099>0.05)

From table 17, it is known that respondents who had a service period of $>10$ years did not complete documentation as many as 50 respondents (49\%) 
Table 18 Results of cross tabulation of the completeness of the $\mathrm{MCH}$ document $(\mathrm{Y})$ with the respondent's workplace.

\begin{tabular}{clllllll}
\hline \multirow{2}{*}{ No. } & Workplace & \multicolumn{3}{c}{ The completeness of document } & \multicolumn{2}{c}{ Total } \\
\cline { 2 - 7 } & \multicolumn{2}{c}{ Scrappy } & \multicolumn{2}{c}{ Complete } & & \\
\cline { 2 - 7 } & F & \% & F & \% & f & \% \\
\hline $\begin{array}{l}\text { Secondary } \\
1 \quad \begin{array}{l}\text { Public health } \\
\text { center }\end{array}\end{array}$ & 26 & 25.5 & 10 & 9.8 & 36 & 35.3 \\
$2 \quad \begin{array}{l}\text { Main Public } \\
\text { health center }\end{array}$ & 44 & 43.1 & 4 & 3,9 & 48 & 47.1 \\
$3 \quad \begin{array}{l}\text { Inpatient Public } \\
\text { health center }\end{array}$ & 17 & 16.7 & 1 & 0.9 & 18 & 17.6 \\
\hline Total & 87 & 85.3 & 15 & 14.7 & 102 & 100 \\
\hline
\end{tabular}

There is a relationship between the workplace and the availability of means ( $\mathrm{p}$ Phi0.0 $022<0.05)$

From table 18 above, it can be seen that the respondents who documented the MCH book did not complete work at the Puskesmas as many as 44 respondents (43.1\%)

Table 19. Results of cross tabulation between variables of respondents' knowledge about the MCH booklet (X1) and the complete MCH book document (Y).

\begin{tabular}{|c|c|c|c|c|c|c|c|}
\hline \multirow{3}{*}{ No. } & \multirow{3}{*}{$\begin{array}{c}\text { Knowledge of the } \\
\text { MCH book }\end{array}$} & \multicolumn{4}{|c|}{ The completeness of document } & \multicolumn{2}{|c|}{ Total } \\
\hline & & \multicolumn{2}{|c|}{ Scrappy } & \multicolumn{2}{|c|}{ Complete } & \multirow[b]{2}{*}{$\mathbf{F}$} & \multirow[b]{2}{*}{$\%$} \\
\hline & & $\mathbf{F}$ & $\%$ & $\mathbf{F}$ & $\%$ & & \\
\hline 1 & Less & 0 & 0 & 0 & 0 & 0 & 0 \\
\hline 2 & Moderate & 9 & 8.8 & 3 & 2.9 & 12 & 11.8 \\
\hline 3 & Well & 78 & 76.5 & 12 & 11.8 & 90 & 88.2 \\
\hline & Total & 87 & $85.3 \%$ & 15 & 14.7 & 102 & 100 \\
\hline
\end{tabular}

There is no relationship between the respondent's knowledge of the completeness of the MCH Handbook documents ( $p$ Phi 0.284>0.05)

From table 19 it can be seen that respondents who have good knowledge but do not fill in the MCH book completely are 78 people $(76.5 \%)$

Table 20 Results of cross tabulation between respondents' workload variables (X2) and the complete KIA book document (Y).

\begin{tabular}{|c|c|c|c|c|c|c|c|}
\hline \multirow{3}{*}{ No. } & \multirow{3}{*}{ Workload } & \multicolumn{4}{|c|}{ The completeness of document } & \multirow{2}{*}{\multicolumn{2}{|c|}{ Total }} \\
\hline & & \multicolumn{2}{|c|}{ Incomplete } & \multicolumn{2}{|c|}{ Complete } & & \\
\hline & & $\mathrm{F}$ & $\%$ & $\mathrm{~F}$ & $\%$ & $\mathrm{~F}$ & $\%$ \\
\hline 1. & Below average & 0 & 0 & 0 & 0 & 0 & 0 \\
\hline 2 & Average & 74 & 72.5 & 14 & 13.7 & 87 & 85.2 \\
\hline 3 & Above average & 13 & 12.7 & 1 & 0.9 & 15 & 14.8 \\
\hline & Total & 87 & 85.2 & 15 & 14.6 & 102 & 100 \\
\hline
\end{tabular}

There is no relationship between the respondent's workload and the completeness of the MCH Handbook documents ( $\mathrm{p}$ Phi 0.390>0.05) 
From table 20 above, it can be seen that respondents who have an average workload do not fill in complete $\mathrm{MCH}$ book documents as many as 74 respondents or $(72.5 \%)$.

Table 21. Results of cross tabulation between the variables of the availability of tools and facilities (X3) and the complete MCH book document (Y).

\begin{tabular}{|c|c|c|c|c|c|c|c|}
\hline \multirow{3}{*}{ No. } & \multirow{3}{*}{$\begin{array}{c}\text { Availability of tools and } \\
\text { facilities }\end{array}$} & \multicolumn{4}{|c|}{ The completeness of document } & \multirow{2}{*}{\multicolumn{2}{|c|}{ Total }} \\
\hline & & \multicolumn{2}{|c|}{ Incomplete } & \multicolumn{2}{|c|}{ Complete } & & \\
\hline & & $\mathrm{F}$ & $\%$ & $\mathrm{~F}$ & $\%$ & $\mathrm{~F}$ & $\%$ \\
\hline 1 & Incomplete & 46 & 45.3 & 11 & 10.7 & 57 & 56 \\
\hline 2 & Complete & 41 & 40.1 & 4 & 3,9 & 45 & 44 \\
\hline & Total & 87 & 85.4 & 15 & 14.6 & 102 & 100 \\
\hline
\end{tabular}

There is no relationship between the availability of tools and the completeness of MCH documents (p Phi 0.141>0.05)

From the 21 above, it can be seen that the respondents had incomplete equipment, did not fill in the complete document of the $\mathrm{MCH}$ booklet, were also incomplete as many as 46 respondents or as many as $(45.3 \%)$

Table 22. Results of cross tabulation between monitoring and evaluation variables of the coordinating midwife (X4) with the completeness of the MCH document (Y).

\begin{tabular}{|c|c|c|c|c|c|c|c|}
\hline \multirow{3}{*}{ No. } & \multirow{3}{*}{$\begin{array}{l}\text { Monitoring and } \\
\text { evaluation of the } \\
\text { coordinating midwife }\end{array}$} & \multicolumn{4}{|c|}{ The completeness of document } & \multirow{2}{*}{\multicolumn{2}{|c|}{ Total }} \\
\hline & & \multicolumn{2}{|c|}{ Incomplete } & \multicolumn{2}{|c|}{ Complete } & & \\
\hline & & $\mathrm{F}$ & $\%$ & $\mathrm{~F}$ & $\%$ & $\mathrm{~F}$ & $\%$ \\
\hline 1 & Not Monev & 19 & 18.6 & 1 & 0.9 & 20 & 19.7 \\
\hline 2 & Monev was carried out & 68 & 66.6 & 14 & $13.7 \%$ & 82 & 80.3 \\
\hline & Total & 87 & 85.2 & 15 & 14.6 & 102 & 100 \\
\hline
\end{tabular}

There is no monitoring and evaluation relationship with the completeness of $\mathrm{MCH}$ documents (p Phi 0.172>0.05)

From table 22 above, it can be seen that respondents who received monitoring and evaluation from the coordinating midwife, but did not complete the $\mathrm{MCH}$ booklet documentation for pregnant women in the third trimester were 68 respondents or as much as $(66.6 \%)$

Table 23. Multi Variet Analysis

\begin{tabular}{lcccc}
\hline Variable & Sig & $\mathbf{R}^{\mathbf{2}}$ & Significant & Exp (B) \\
\hline Knowledge (X1) & & & 0.031 & 0.301 \\
Availability of tools (X3) & 0,000 & $62.6 \%$ & 0.025 & 0.241 \\
$\begin{array}{l}\text { Monitoring and evaluation of } \\
\text { the coordinating midwife (X4) }\end{array}$ & & & 0.035 & 6,969 \\
Workload (X2) & & & 0.647 & 0.656 \\
\hline
\end{tabular}

Based on table above it can be seen;

1. Variable Knowledge of respondents about the MCH Handbook (X1) can partially affect variable Y: The completeness of the $\mathrm{MCH}$ Handbook document for third trimester 
pregnant women (Exp.B 0.301) with a value (Sig, 0.031) < $\alpha(0.05)$ so that $\mathrm{H} 1$ is accepted.

2. The Workload variable (X2), the significance value of $(0.647)$ is much greater than the value ( $\alpha$ $0.05)$, so $\mathrm{H} 1$ and $\mathrm{H} 0$ are accepted.

3. The variable availability of tools and facilities (X3) can affect the variable of KIA book document completeness (Y), the size of the effect is (Exp.B 0.241) with a significance value of $(0.025)<\alpha(0.05)$ so that Reject $\mathrm{H} 0$ and $\mathrm{H} 1$ are accepted

4. The monitoring and evaluation variable of the coordinating midwife (X4) can affect the variable of MCH handbook document completeness (Y) of (Exp.B 6.969) with a significance value $(0.035),<(\alpha 0.05)$ so that $\mathrm{H} 0$ is rejected and $\mathrm{H} 1$ is accepted.

5. Simultaneously, the influence of the Respondent Knowledge variable (X1), the availability of tools and facilities (X3), and the Coordinating Midwife Monitoring and evaluation variable (X4) on the variable $\mathrm{MCH}$ handbook document completeness (Y) is $62.6 \%$, (Nagelkerke R Square coefficient ) $37.4 \%$ influenced by external factors that were not examined.

6. It can be concluded that the dominant factor that most influences the completeness of the $\mathrm{MCH}$ Handbook document for third trimester pregnant women in West Kotawaringin is the monitoring and evaluation variable by the coordinating midwife (X4) of (Exp.B $6,969)$.

\section{DISCUSSION}

A. The effect of the knowledge of midwives about the MCH handbook on the completeness of the MCH handbook document as an early detection of high-risk third trimester pregnant women in West Kotawaringin.

Meanwhile, 12 midwives with good knowledge and complete MCH Handbook documents were 12 midwives (11.8\%) and 3 midwives with knowledge of the $\mathrm{MCH}$ booklet and filled in the $\mathrm{MCH}$ book completely (2.9\%). The result of 15 respondents (14.7\%) who filled in the MCH booklet documents completely, all of them were respondents with D-III Midwifery education. Knowledge is the result of tofu, and this happens after people sensing a certain object. Sensing occurs through the human five senses, namely the senses of sight, hearing, smell, taste and touch. Most of human knowledge is obtained through the eyes and ears (Notoatmodjo, 2015). According to (NotoAdmojo, 2015),

The MCH Handbook is a tool for early detection of maternal and child health problems or problems, a communication tool and a tool for counseling with important information for mothers and families and the community regarding maternal and child health services including references and packages (standard) of $\mathrm{MCH}$ services, nutrition, immunization and development of children under five. The Maternal and Child Health Book also contains important information needed by mothers and families that must be conveyed by health workers through information and education communication to increase knowledge and health behavior of pregnant women and their families so that mothers and families are able to maintain, monitor and improve health. pregnant women and their fetuses as well as mothers and their families recognize danger signs as early as possible in pregnant women so that management can be done quickly. This can reduce the incidence of high-risk pregnant women and reduce maternal mortality (Kemenkes 2015). Previous research by Rahayu Norma cahyani, Yudhy Darmawan, Darminto in 2016 with the title "Several factors related to the completeness of filling and utilization of $\mathrm{MCH}$ book data by village midwives in Sragen district in 2016" shows that most of the data filled in by village midwives in the district. Sragen was incomplete (61.8\%), greater than that which was filled with complete midwives. 
The researcher is of the opinion that the midwife's knowledge of the $\mathrm{MCH}$ handbook in Kotawaringin Barat district only reaches the Know and understand level, not yet at the application or use level. This is proven by the data tabulation of the frequency of midwives who have knowledge of the $\mathrm{MCH}$ booklet, which is 90 midwives (88.2)\%, but in the tabulation of the frequency of completeness of the $\mathrm{MCH}$ book documents, only 15 midwives fill out the $\mathrm{MCH}$ book document completely $(14.7 \%)$. In the field, the researchers also found that there were differences in perceptions by the midwives about the importance of completing the $\mathrm{MCH}$ document, in several places the research showed that there was a record of planning for delivery of pregnant women $(\mathrm{P} 4 \mathrm{k})$ recorded on an accountability sheet which became the absorption of program funds, but the statement sheet welcoming a safe delivery in the MCH Handbook for pregnant women is actually not filled in. Of the 4 indicators (identity sheets, welcome sheets for safe delivery, P4K stickers and health records for pregnant women, midwives must fill in documentation for pregnant women, the most frequently not filled sheet is the sheet welcoming a safe delivery, even though this sheet is one package with sticker sheet

\section{B. Effect of Workload on Completeness of MCH Handbook documents as early detection of high-risk third trimester pregnant women in West Kotawaringin}

In this study, the results of the workload variable have a significant value of $(0.647)$ much greater than the value $(\alpha 0.05)$, the hypothesis that says there is an effect of workload on the completeness of the MCH Handbook Document in Trimester III pregnant women in West Kotawaringin is stated in refuse. The results of cross tabulation between the workload and the completeness of the $\mathrm{MCH}$ booklet documents for trimester III pregnant women found that 74 respondents (72.5\%) had an average workload of filling in the $\mathrm{MCH}$ booklet documents for pregnant women in the third trimester, while respondents with a workload above average as many as 14 people (13.7\%) filled out incomplete $\mathrm{MCH}$ documentary documents, much higher than respondents who filled in complete $\mathrm{MCH}$ document documents, both in the category of average workload and above average,

Based onThe results of cross tabulation between workplaces and complete $\mathrm{MCH}$ book documents were obtained from 15 respondents who filled in the MCH booklet documents completely, 10 respondents $(9.8 \%)$ worked at Secondary Public Health Center. 4 respondents (3.9\%) worked at non-inpatient primary health centers and 1 respondent $(0.9 \%)$ worked at inpatient health centers, the results of cross tabulation between workplaces and the completeness of the $\mathrm{MCH}$ book, obtained significant results (p. 0.022) $<(\alpha 0.05)$. Based on the results of cross tabulation between the working period and the completeness of the MCH booklet document for trimester III pregnant women, the results obtained from 15 respondents $(14.7 \%)$ who filled in the complete MCH book document, 12 respondents $(11.8 \%)$ had a work period of more than 10 years. Verify the results of the cross tabulation between the age of the respondent and the complete $\mathrm{MCH}$ document document.

Workload is a number of processes or activities that must be completed by a worker within a certain period of time. If someone completes and adjusts to a number of assigned tasks, then this does not become a workload. However, if the worker does not succeed, the tasks and activities become a workload (Muchlisin Riadi, 2018) Workload is the amount of work that must be borne by a person. Position/organizational unit and is the product of work volume and time norms (Permendagri no 12/2008)

The results of the research in Sragen Regency showed that there was a relationship between workload and completeness of filling in the data on the $\mathrm{MCH}$ book by village midwives with a $\mathrm{p}$ value $(.001)<(0.05)$. The results of research in Sragen Regency show that high workloads can affect village midwives in carrying out their main duties in filling out the $\mathrm{MCH}$ booklet. This is not in line with the results of the study "Analysis of factors that affect the completeness of the MCH booklet document for third trimester pregnant women by midwives in West Kotawaringin".

The researcher is of the opinion, Respondents who work in the village or in the main puskesmas network Secondaru Public Health Center know more about clients and their families so that the information or documents that will be filled in the $\mathrm{MCH}$ book are widely known by the respondents. In addition, respondents who have The work period of more than 10 years in the same workplace, the respondent has long interacted with the client's work and family goals (pregnant 
women). This was found in respondents who had a work period of 20 years at the same time, respondents followed the process of pregnancy to delivery of the pregnant mother from the first child to the 3rd child. In addition, respondents with a work period of more than 10 years have more working experience, and can analyze the importance of completing the $\mathrm{MCH}$ book document.

\section{Effect of availability of tools and facilities on the completeness of the MCH Handbook document as an early detection of high-risk third trimester pregnant women in West Kotawaringin.}

In the variable availability of tools, based on logistic regression analysis, the results of the significance $(0.025)$ were smaller than the value $(\alpha 0.05)$, the hypothesis that there was an effect of the availability of tools and facilities on the completeness of the $\mathrm{MCH}$ booklet document for pregnant women in the third trimester by midwives in West Kotawaringin in October 2019 can be received. The results of the cross tabulation between the availability of tools and facilities for the completeness of the $\mathrm{MCH}$ book documents, where the results obtained for respondents who had incomplete tools, the $\mathrm{MCH}$ book documents were not filled completely as many as 46 respondents $(45.3 \%)$, while the respondents who had availability 11 respondents (10.7\%) were able to fill in complete MCH book documents but were able to fill in the complete $\mathrm{MCH}$ booklet documents as many as 11 respondents (10.7\%). 7\%) who filled out the complete $\mathrm{MCH}$ book documentation, it turned out that 12 respondents $(11.7 \%)$ were in the $>35$ years age group. And it is stated that there is an effect of the respondent's age on the completeness of the MCH booklet document for pregnant women in the third trimester by midwives in West Kotawaringan, where the significance value is $\mathrm{P}$ value ( $\mathrm{p}$ Phi 0.028 ) $<(\alpha 0.05)$

Medical devices are instruments, apparatus, machines and / or implants that do not contain drugs that are used to prevent, diagnose, cure and alleviate disease, treat sick people, restore health in humans, and / or form structures and improve body functions. (Permenkes no.62 of 2017) Health service infrastructure can be defined as a collaborative process for the utilization of all health facilities and infrastructure effectively and efficiently to provide professional services in the field of facilities and infrastructure in an effective and efficient health service process (Muhammad, 2010 in Ida Yunari Ristiani, 2017).

In a previous study by Trianasari in 2012, regarding the factors affecting the completeness of MCH book filling by midwives in Banyu Mas Regency, it was found that the completeness of filling in the $\mathrm{MCH}$ books was complete with the proportion of complete facilities (68.9\%) greater than those with less complete facilities 51.3\%). The completeness of filling in the $\mathrm{MCH}$ booklet that is incomplete with the proportion of support for incomplete facilities $(48.7 \%)$ is greater than that for complete facilities $(31.1 \%)$.

When they are faced with certain cases of resti that do not have complete $\mathrm{MCH}$ documentary documents, it will make it difficult for them to make clinical decisions that they will take, secondly, apart from experience, respondents aged> 35 years have had many opportunities to learn or train related to filling the $\mathrm{MCH}$ booklet properly and correctly. The work place of the midwife also greatly affects the completeness of filling in the $\mathrm{MCH}$ booklet documents, if the midwife works at the Main Public Health Center Network (Secondary Public Health Center) which does not have laboratory equipment, or the laboratory examination must be carried out by Specialized personnel such as an Analyst, the midwife concerned must refer to the main health center, for screening several laboratory examinations, the obstacles faced by midwives who work at the secondary public health center, not all pregnant women are willing to go to the main public health center considering the distance, this is one of the reasons that midwives in Kotawaringin Barat are incomplete filling MCH booklet documents. However, for public health center that have implemented the integrated ANC program, they have scheduled visits to the main staff to the network (secondaru public health center) and it has been running well, then the health record sheet for pregnant women can also be filled in completely. In the field, it was also found that there were several reagents / RDTs that agreed with the triple elimination program (HIV, HBsAg and Syphillis) in several public health center stating that the stock was limited, so that there were several examinations they could not do that supported the completeness of the $\mathrm{MCH}$ booklet document for pregnant women in the third trimester. in West Kotawaringin. 


\section{The Effect of Monitoring and Evaluation of Coordinating Midwives on the completeness of the MCH Handbook document as an early detection of high-risk third trimester pregnant women in West Kotawaringin.}

The results showed that the monitoring and evaluation variables of the coordinating midwife on the completeness of the $\mathrm{MCH}$ documentary book as an early detection of high-risk pregnant women in the third trimester in West Kotawaringin, stated that the logistic regression test obtained a significance result $(0.035)<(\alpha 0.05)$, so the hypothesis can received the magnitude of the influence is stated at (Exp B: 6,696) or 7 times the effect. Then the variable (X4) is the most influential (dominant) factor on the completeness of the MCH booklet documents in trimester III pregnant women by midwives in October 2019 From the results of cross tabulation between variables Monitoring and evaluation by the coordinating midwife on the completeness of the $\mathrm{MCH}$ book document, obtained results from 102 respondents, 82 respondents $(80.3 \%)$ received monitoring and evaluation by the coordinating midwife. but 14 respondents (13.7\%) filled out the complete MCH book document. And 1 respondent $(0.9 \%)$ even though they did not receive monitoring and evaluation by the coordinating midwife, they could complete the $\mathrm{MCH}$ booklet for pregnant women in the third trimester.

Definitionmonitoring (monitoring) is; activities to assess or ensure that intermediate results can be achieved, meanwhile, the definition of evaluation is; activities to assess whether the final results of an activity / program are achieved as planned. Coordinating midwives are: Midwives in health centers or district / city health offices who because of their abilities have the responsibility of fostering midwives in their working areas as individually or in groups (Kemenkes RI, 2010). In previous research in Sragen Regency in 2016, the report on the relationship between supervision and completeness of filling in the MCH booklet data by midwives about completing the MCH booklet was obtained by a value of Pvalue (0.786)> 0.05 in bivariate analysis, so it was stated that there was no relationship between supervision and completeness of filling in data in the KIA book.

The researcher is of the opinion that, although the frequency data showing the monitoring and evaluation activities of coordinating midwives is quite good, namely from 102 midwives, 82 midwives have received monitoring and evaluation (80.3\%), but 82 midwives received monitoring and evaluation by midwives. only 14 midwives (13.7\%) filled out the $\mathrm{MCH}$ booklet document. And there was 1 midwife who, although not receiving monitoring and evaluation by the Coordinating midwife, still carried out complete documentation in the KIA book. The reality in the field shows that the monitoring and evaluation carried out by the coordinating midwife is not focused on filling in the complete $\mathrm{MCH}$ document documents, but is integrated into other $\mathrm{MCH}$ activities, so that monitoring and evaluation of the MCH Handbook is not a priority scale in carrying out supervision.

\section{E. The dominant factor influencing the completeness of this MCH Handbook document is the early detection of high-risk third trimestes pregnant women by midwives in West Kotawaringin.}

Simultaneously the influence of the Respondent Knowledge variable (X1), the Availability of tools and facilities (X3) and the Coordinating Midwife Monitoring and evaluation variable (X4) on the variable. The completeness of the KIA book document $(\mathrm{Y})$ is $62.6 \%$, (Nagelkerke R Square coefficient), $37.4 \%$ is influenced by external factors that are not examined. Partially the knowledge variable (X1) has an effect of (Exp B: 0.301), the variable availability of tools and facilities (X3) has an effect of (Exp.B: 0.241), while the monitoring and evaluation variable by the coordinating midwife (X4) is (Exp. .B 6,969), is the greatest value from the influence of other variables.

This is in line with the Coordinating Midwives Technical Guidelines, concerning the first Duties and functions of the Coordinating Midwife, which is to supervise, monitor and evaluate the performance of midwives in their working areas regarding the clinical aspects of the profession and management of the MCH program. (Indonesian Ministry of Health, 2013) The MCH Handbook is one of the logistical needs that must be available at a midwife's workplace, so that midwives can carry out 
complete documentation, the $\mathrm{MCH}$ handbook is given since the first visit / contact (K1) of pregnant women, in the main task of the midwife Coordinator Monitoring, supervising and evaluating programs $\mathrm{MCH}$ includes an assessment of infrastructure and logistics (supporting facilities), clinical performance and managerial performance of midwives in their working area. (Indonesian Ministry of Health, 2015). The duties and functions of Bikor are closely related to the supervisory function, compared to the monitoring and evaluation functions which are more of the duties and functions of the above positions (Head of Puskesmas and District Health Office). Bikor acts as a supervisor for midwives in their working area, especially for village midwives who work in Pustu / Polindes / Poskesdes.

In this case the researcher is of the opinion, Monitoring and evaluation by the coordinating midwife must continue to be carried out effectively and facilitatively, scheduled and agreed upon. Even though it is integrated with other MCH programs, in this study, monitoring which is focused on the completeness of the $\mathrm{MCH}$ book document by the coordinating midwife is very important. has a major effect on the success of service delivery, including documentation in the $\mathrm{MCH}$ booklet for trimester III pregnant women. With the complete $\mathrm{MCH}$ booklet document for pregnant women in the third trimester, it can provide information on the health track record of pregnant women, including accompanying diseases, making it easier for other health workers to determine the direction in the right clinical decisions, so as to reduce maternal and infant mortality rates.

\section{CONCLUSION}

Based on the research results, it can be concluded that:

1. There is an effect of midwives' knowledge of the KIA book, on the completeness of the KIA book documents in West Kotawringin in October 2019, with a value of (Sig: 0.031) $<(\alpha 0.05$ )

2. There is no effect of workload on the completeness of the MCH booklet document for pregnant women in the third trimester in West Kotawaringin in October 2019 with a value (Sig: 0.647)> $(\alpha$ $0.05)$

3. There is an effect of the availability of tools and facilities on the completeness of the MCH Handbook document for pregnant women in the third trimester of West Kotawringin. With the value (Sig: 0.025$)<(\alpha 0.05)$

4. There is an effect of monitoring and evaluation by the coordinating midwife on the completeness of the MCH Handbook document for pregnant women in the third trimester of West Kotawringin. With the value (Sig: 0.035) $<(\alpha 0.05)$

5. The dominant factor that greatly influences the completeness of the MCH documentary documents is the monitoring and evaluation variable by the Coordinating midwife with (Exp.B: 6,969), meaning that monitoring and evaluation by the Coordinating midwife affects the completeness of the MCH book document

6. From the results of this study with 102 midwives in West Kotawaringi, it was found that 15 midwives $(14.7 \%)$ were able to fill in good and correct documents, while 87 respondents $(85.3 \%)$ had dominated the MCH booklet for trimester pregnant women. III, but it has not reached $80 \%$ completeness on the 4 indicators.

\section{Suggestion}

1. For Respondents

To all midwives to always apply the proper and correct SOP for filling the $\mathrm{MCH}$ booklet for pregnant women, at least $80 \%$ of the completeness of the documents on 4 indicators
a. Identity Sheet
b. Sheets welcome safe delivery
c. P4k stickers
d. Maternal health record sheet.

2. For research sites, 18 Puskesmas Kotawaringin Barat Health Service

a. Can complete the technical manual for filling in the MCH Handbook in the work unit (Puskesmas) 
b. There are always tools, instruments, or reagents needed to perform integrated ANC. ( Public health Office)

c. Can run the integrated ANC program at puskesmas and its networks, especially pustu and polindes that do not have laboratory facilities, because this greatly affects the filling of the $\mathrm{MCH}$ booklet documents for pregnant women in the third trimester. (Head of Puskesmas)

d. Always implement SOP compliance monitoring for the filling of the MCH Handbook by the Midwives (Bidan Koordinator)

e. Provide training or workshops on the negligence of filling out the $\mathrm{MCH}$ booklet properly and correctly. (Health Office and Head of Puskesmas) 3

3. For Further Researchers

For further researchers, it is necessary to deepen and add other variables that have not been studied that can affect the completeness of the MCH Handbook document in third trimester pregnant women.

\section{ACKNOWLEDGMENTS}

The researcher would like to thank all midwives in Kotawaringin Barat district who helped with data collection.

\section{CONFLICT OF INTEREST}

The author declares that no conflict of interest in this research.

\section{REFERENCES}

Ministry of Health RI, 2010 Integrated Antenatal Guidebook: Jakarta

N. Elly, Kristiani, and S. Werdati, "The use of the KIA book as a material for counseling in anatenatal services by midwives at the Puskesmas in Bengkulu City," J. Manaj. Health services., vol. 06, no. 03, pp. 155-162, 2013.

N. Cahyani, Y. Dharmawan, B. Biostatistics, and Community FK, "Several factors related to Completeness of Filling and Utilization of Data on Kia Books by Village Midwives in Sragen Regency in 2016," J. Kesehat. Masy., Vol. 4, no. 4, pp. 238-246,

Nursalam, 2016. Concept and Application of Nursing Research Methodology. Jakarta: Salemba Medika

Notoatmodjo, Soekidjo. 2010. Health Research Methodology. Jakarta: Rineka Create

Onajiati, Umika. 2013. Resti Pregnancy (High Risk). http://umikaon.com

Prawirohardjo, Sarwono, 2014, Midwifery, Jakarta: Bina Pustaka Foundation - Sarwono Prawirohardjo.

Riskesdas. 2018. Coverage of MCH book ownership for pregnant women. Jakarta

Ristiani Ida Yunari, 2017 the influence of facilities and infrastructure and service quality on patient satisfaction, accessed on July 30, 2019. http // 72.idayunaari@gmail.com

Tri Anasari, 201 Factors Affecting Completeness of Filling

MCH Handbook By Midwives In Early Detection of High Risk Pregnancy

At the Banyumas District Health Center in 20122, accessed 17 July

2019.http//akbid.ylpp@gmail.com 